\title{
The Incidence of Economic Freedom and Foreign Direct Investment in Economic Growth: Empirical Evidence from Tunisia
}

\author{
Kaddachi Hayet", Ben Zina Naceur \\ Economic Science, Faculty of Economics and Management, University of Sfax, Sfax, Tunisia \\ Email address: \\ Kaddachihayet.123@gmail.com (K. Hayet),nzzinnin@yahoo.fr (B. Z. Naceur) \\ ${ }^{*}$ Corresponding author
}

To cite this article:

Kaddachi Hayet, Ben Zina Naceur. The Incidence of Economic Freedom and Foreign Direct Investment in Economic Growth: Empirical Evidence from Tunisia. International Journal of Health Economics and Policy. Vol. 6, No. 1, 2021, pp. 23-30.

doi: $10.11648 /$ j.hep. 20210601.13

Received: September 14, 2020; Accepted: November 26, 2020; Published: March 26, 2021

\begin{abstract}
Economic freedom is one of the most important factors in increasing economic growth. Thus, it affects the spillover effects of FDI through the improvement of the absorption capacity in the host countries. In this context, this thesis aims to study the macroeconomic impact of economic freedom on foreign direct investment inflows by basing empirical evidence for data from Tunisia over a period from 1980 to 2017. Using the famous economic method of generalized moments (GMM), the results of the estimates show that FDI positively affects economic growth and requires a high level of economic freedom, and makes it possible to increase the absorption capacity in host countries and " attract more investors. Economic freedom increases FDI inflows to 0.098 units. More precisely, Tunisia also refers to the positive impact of economic freedom on FDI.
\end{abstract}

Keywords: Economic Freedom, Foreign Direct Investment, Economic Growth, GMM

\section{Introduction}

The research attempts to validate the existing literature on the relationship between foreign direct investment and economic freedom. In this context, we focused on one of the Arab countries affected by political and economic instability, and which was seen as the origin of the Arab Spring. In this study, we try to bridge this gap by analyzing aggregate data from Tunisia over a period from 1980 to 2017. The study aims to also provide an overview of the interaction of foreign direct investment inflows with the level of economic freedom.

The impact of foreign direct investment (FDI) on growth has been extensively developed in the economic literature. Therefore, in recent years, the strong point for this area of research has also been the shift in the focus of political actors to attract more FDI. Indeed, since the 1980s, several countries (including developing countries) have lifted many of the restrictions on foreign capital flows. However, in 2001 shows that global investment inflow have decreased by 18 percent to US \$ 1,350 billion.

Indeed, only the African continent recorded a 5\% increase of these flows, which explains why almost $17 \%$ of this increase is absorbed by Tunisia, which occupies the third place in the countries of North Africa by increase $15 \%$ of its stock. During the period of the revolution, Tunisia remains attractive in terms of FDI and recorded a 55\% increase between 2012 and 2011, which shows that it is able to cope with internal and external shocks and increases volatility. Inflows attract massive new investors from France and Great Britain.

Since the early 1970s, Tunisia has pursued a policy of economic openness to attract FDI and take advantage of comparative advantages in abundant and relatively skilled labor. In terms of quality, these flows and capital inflows are directed towards the electrical, pharmaceutical and electronic industries, and are a real evolution.

The low level of FDI is due to the weak absorptive capacity of the host country. Generally, FDI dynamics are conditional on certain fundamental factors such as the nature of the regulatory framework of economic freedom. Indeed, common sense generally recognizes that without a stable institutional environment and an efficient legal system, it is difficult to 
make FDI flows more attractive in the world. While the quality of the regulatory framework is considered a crucial factor in attracting FDI and benefiting from new development strategies, there is less theoretical and empirical research on the impact of regulatory institutions on economic growth.

FDI has generated a number of controversies, for the first time the International Monetary Fund [1] defined FDI as an investment intended to acquire a lasting interest in a company operating in the territory of an economy other than that of investment. Then, in 2011, the Banque de has shown that "FDI is an international investment through which entities resident in an economy acquire a lasting interest in an entity resident in an economy other than that of the investor". At this level, the growing importance of FDI in the literature shows the existence of a lasting relationship to understand the link between FDI flows and economic growth.

Overall, this study is structured as follows: the first section presents an introduction. The second section deals with the review of the literature which explains the impact of FDI on growth on the one hand and the impact of economic freedom on FDI on the other hand. Thus, in the third section, we focus on the methodology used to conduct the research. The fourth section presents the empirical results of the research. Finally, we end with a conclusion.

\section{Literature Review}

\subsection{Relationship Between FDI and Economic Growth}

According to Dunning, $\mathrm{Xu}$, Kohpaiboon, Worth and Nath FDI is considered to be a fundamental factor thanks to the positive technological development it generates and the diffusion of international technologies that allow local businesses to take advantage of advanced techniques [2, 6].

Alfaro et al. [7] have shown that an effect in terms of knowledge and technology transfer to the host country under certain conditions of availability of human capital implies a real relationship between FDI flows and economic growth. Likewise, Blomströmom et al [8] revealed that the penetration of new multinational firms in the market is complemented by the entry of new technologies that make competition more competitive in the host country.

In this context, when the level of education is high, it helps to improve the skill levels of the local workforce; in this case, the stock of human capital is a crucial factor to increase the wealth of the country.

This is why Zghidi et al [9] amazed that the absorption of the benefits of FDI by host countries depends on a certain factor namely good trade policies as well as the presence of human capital.

However, a number of studies on FDI have noted that the presence of these investment flows has generated positive effects on the economic activities of local businesses, indeed, the massive influx of foreigners and capital generates perverse consequences on the freedom of investment.

Krugman [10] confirms this idea and points out those international investors can benefit from significant liquidity when selling capital to domestic investors. In this context, Stiglitz [11] has shown that the liberalization of capital has harmful consequences on the macroeconomic stability of developing countries in the event of deficiencies in regulatory institutions.

Alaya et al [12] asserted that participation in privatization transactions of existing companies, and the use of joint venture agreements with neighboring companies leads to productivity improvements, which have positive effect on the growth, and wealth of the country. The idea is also confirmed by the studies of Aitken et al [13]. At this level, FDI contribute to increasing economic growth thanks to the opening of the host country to trade and the absence of trade barriers and subsidies, which encourage the export of foreign companies and facilitate the technology transfer and access to competitive markets.

The positive effect of FDI on domestic investment is manifested through several channels such as the transmission of quality control techniques to their supplier. Indeed, Agosin and Mayer [14] state that domestic investment increases through increased competition and efficiency and the introduction of new knowledge.

Ersoy, a. Y., and Aalioua, M [15] have shown that based on the importance of technology transfers and management activities, associations of foreign investors can benefit more. Indeed, FDI could benefit more from technical progress, in particular through the training of local personnel, the improvement of the production of multinational companies as well as the strengthening of the capacity of national investors to compete. Finally, the impact of FDI on growth requires the existence of economic freedom as an interaction variable. The following literature we show the importance of economic freedom as a proxy that allows promoting the increase of FDI inflows and improving economic performance and growth.

Mohamed, S. E., and Sidiropoulos, M. G. [16] developed the main determinants of foreign direct investment in MENA countries based on a sample made up of 36 countries. Indeed, 12 of these countries belong to the MENA region and 24 countries are considered recipients of FDI in their respective regions of the countries. To do this, they used a panel data methodology, aimed at knowing whether the determinants of FDI are similar to those of other developing countries receiving FDI.

These two authors revealed that the main determinants of FDI inflows into MENA countries are represented by the size of the host economy, the size of the government, natural resources and institutional variables. In this context, the estimate showed that countries that receive less foreign investment could make themselves more attractive to potential foreign investors. Thus, policy makers in the MENA region should remove all trade barriers, and develop their financial system in order to put in place appropriate institutions.

The purpose of the contribution made in this article is twofold: first, we assume that the only study that analyzes the interaction between IDE and economic freedom and growth in Tunisia. Secondly, the conclusions drawn encourage investors to attract more FDI inflows into an attractive region characterized by an enabling environment and good absorptive capacity. The main objective of this paper is to 
study the role of economic freedom in the compromise of the impact of FDI on economic growth in Tunisia over a period. The first section will consist of presenting a theoretical examination that focuses on the impact of FDI and economic freedom on growth on the one hand, and on the other hand, on the interaction relationship that exists between economic freedom and economic freedom. IDE. Thus, the second section will present our model and the estimation methods used, and the third section will present the estimation results obtained. Finally, we will end with the conclusion.

\subsection{Relationship Between Freedom Economic, FDI and Economic Growth}

Nowadays, several theoretical journals are interested in analyzing the relationship between economic freedom and FDI and economic growth. According to Gwartney [17] a researcher at the Fraser Institute, people enjoy economic freedom if, on the one hand, their properties are protected, and on the other hand, they are free to use, exchange or dispose of their properties. To the extent that their actions do not violate the rights of others. There are many potential freedom measures to use. An issue developed in Global Economic Freedom Rating (1992). The first group represents what will become a continuing project funded by the Fraser Institute: Others have not been updated. According to Gwartney [18] and Hall, J. C., and Lawson, R. A [19] collected a measurement indicator for the quality of institutions called "global index of economic freedom" based on the institutional literature this index is published by the Fraser Institute.

It is considered the best index to instruct the method whose market institutions that maintains the autonomy of choice and introduces the plural properties of the means of production and exchange. On a scale from 0 to 10 , this index classifies the countries from least free to most free, it is based on five areas (the size of the government, price stability, the legal system, the protection of property rights private, freedom of commerce). Recent studies in this area come together to describe a positive relationship between the institution and other decisive factors for the amelioration of the country's growth. The economic founders agreed on the function of economic freedom that allocates resources and distributes them efficiently among agents. They see that civil liberty and political freedom are one of the pillars of the country's institutional structure.

In the study of Azman-Saini [20], we note that the systemic link between economic freedom, foreign direct investment (FDI) and economic growth on a panel of 85 countries is justified. Indeed, the empirical results of this article were based on the generalized method of moments; they revealed that FDI in itself has no direct (positive) effect on output growth. Instead, the effect of FDI depends on the level of economic freedom in the host countries. This means that countries promote greater freedom of economic activities and benefit significantly from the presence of multinational companies.

In the same context, Rahim Quazi [21] he focused on the pillars of economic freedom to attract more FDI and improve the adoption of new technologies, taking into account the importance of the reforms adopted to improve the impact of FDI. At this level, he examined the effect of the collision of economic independence on the flow of foreign investment on panel data based on a sample made up of seven major East Asian countries over a period ranging from from 1995-2000. He used a fixed and random effect model and found that $70 \%$ of FDI is explained by its first lag. Subsequently, he also concluded that political instability and market size variables in the random effects model are very significant.

The work of Fabro and Aixala [22], examined the relative impact of economic freedom, civil liberties and political rights on economic growth. These authors used a system of three simultaneous equations to discover the channels through which these institutional dimensions affect economic growth. These include greater efficiency and increased investment in physical and human capital. They were based on a sample of 79 countries and 6 periods covering the years 1976 to 2005 . At this level, the results of this study show that the three dimensions of institutional quality are important for the improvement of economic growth either by a better allocation of resources, or, indirectly, by stimulating investments in human capital.

Jac C. Heckelman demonstrated that the literature on freedom and growth has consistently shown that countries that have less restriction on private agents and transactions tend to have higher levels of economic growth [23]. However, it is less clear whether freedom causes growth, growth causes freedom, or both are jointly determined. At this level, to assess these possibilities, Heckelman performed an econometric model based on annual freedom indicators developed by the Heritage Foundation and national growth rates. As a result, the composite index include the trade policy, taxation, monetary policy, capital flows and investment, banking, wage and price controls, government intervention, property rights, regulation and black markets are also tested in addition to rating. Indeed, these tests suggest that the average level of freedom in a nation, along with many specific underlying elements of freedom, precedes growth. However, growth can precede one of the component indices (government intervention), and no relation is found between growth and two of the indices (trade policy and taxation).

Sambharya and Rasheed examined the macroeconomic impacts of economic and political freedom on FDI flows to 95 host countries by analyzing the team's data over the periods 1995-2000 [24]. Their findings indicate that before benefiting from the inflows of foreign direct investment, countries must insist on better economic management in terms of sound monetary policy, financial burden, banking services and financing. In addition, they argue that less government participation in the economy, stronger property rights, a low prevalence of informal markets and less corruption are desirable for more foreign direct investment.

Pearson et al. demonstrated the impact of economic freedom and growth on FDI. They based on an analysis of panel data from 50 countries over a period from 1984 to 2007 using a random effects model [25]. They found that economic 
growth and economic freedom have a significant positive impact on FDI in all states. Similarly, these authors also explained that per capita income and the unemployment rate have a negative effect on FDI. In addition, they approached these relationships with the fact that states have higher per capita incomes allowing for increased FDI inflows because higher income yields higher wages, and a high unemployment rate is positively related the worsening percentages of crime.

Eva Medina-Moral and Vicente J. Montes-Gan provided empirical evidence on the institutions most likely to foster development at its different stages [26]. First, they identified three stages of development that prevailed in the world between 1996 and 2011 according to the World Bank's income classification corroborated by data from the UNDP Human Development Index. Then, they considered that a country behaved "successfully" if its stage of development was improved during this period. Indeed, the fact of grouping countries according to "success", rather than according to the level of income, this allows to introduce the dynamics of development in the analysis. In addition, these authors formulated a data panel and a probit model to determine which institutions are behind the success stories. They found results that identify economic freedom as the most important institution of all stages of development, in this case governance was also considered essential, but only in countries in the mid-stage of development.

Contrary to the existing literature, Y. Sovbetov [27] aims to study the macroeconomic impact of economic freedom on foreign direct investment inflows in both global and regional panel analyzes for 156 countries over the periods 1995-2016. The sample includes often over looked countries such as fragile and conflict-affected states, sub-Saharan countries, Oceania, and post-Soviet countries. However, the latter study not only examines the overall impact of economic freedom on FDI inflows, but also does a regional analysis. In this regard, they found a positive impact of economic freedom on FDI under a fixed-effects model in the global case where there is a change in the unit of economic freedom that generates an improvement in FDI inflows at 1.15 units. More precisely, the results gave positive and significant signs for the impact of economic freedom on FDI in the 9 regions. In this context, they noticed as well, that the highest impact is recorded in European countries, while the lowest is recorded in state, which are affected, by Oceania and fragile conflicts.

From the same research perspective, Sooreea-Bheemul, et al [28] focused on the issue of the impact of economic freedom on inward foreign direct investment in sub-Saharan Africa. they used disaggregated measures of economic freedom from the Heritage Foundation and the Fraser Institute to uncover which components of economic freedom matter for inward FDI in a sample of 40 countries in sub-Saharan Africa over the period 1997-2016. Indeed, they estimated panel data based on a fixed and random effects model. These authors have shown that greater overall economic freedom is a key determinant of FDI entering the sample in question. However, there is clear evidence that efficient business freedom, and fiscal freedom, commercial openness, and sound telecommunications infrastructure are very important in attracting foreign investors and accumulating capital flows in the country. region. Likewise, the estimate showed the importance of price stability and the independence of the banking and financial sector which improves the freedom of investment and the freedom of trade and consequently makes it possible to attract FDI.

Suleymanov, Elchin and Alirzayev, Elvin [29] they confirmed the need for FDI for the developing economy. Therefore, they noticed that the majority of these countries, suffer from the lack of investment savings, and compete to attract investments and fight against poverty. More explicitly, they argue, in competition, they realize that economic freedom must be improved for investment to reach the economy. For this reason, the authors analyzed the key factors to improve the situation in order to attract capital flows, and make them attractive with the level of freedom of other countries studied in theory and in practice, as well as the current level of freedom. Economy of Azerbaijan and its improvements. Moreover, they explained the sharp drop in oil prices since 2015, which forced the government to devalue the currency twice, has led to government reforms in the non-oil sector in the country.

Singh, D., and Gal, Z [30] examined the impact of economic freedom on foreign direct investment inflows on a large sample of eight groups (South Asia, East Asia and Latin America, Middle East and North Africa, Northern Europe, Southern Europe, Western Europe, Eastern Europe and Sub-Saharan Africa). They used data from the Heritage Foundation Index of Economic Freedom over the period 1999 to 2018 and went through the multiple regression of all components of the Index of Economic Freedom. In this context, they found results that verify the positivity and significance of economic freedom in South Asia, Latin America, East Asia, Northern Europe and Western Europe. However, for the Middle East and North Africa, the economies of Eastern and Southern Europe, EF has an insignificant positive influence. Arslan, A., Tarba, S. Y., and Larimo, J. [31] have discussed the entry strategies of foreign direct investment of multinational companies. They based on an empirical sample composed of 348 investment operations carried out by 146 Nordic companies (Denmark, Finland, Norway and Sweden) in the less studied transitional periphery of the European Union namely the Commonwealth of States independent and South-Eastern Europe between 1990 and 2009. Indeed, the results found by these authors revealed that a great distance of economic freedom leads to prefer investments in new fields.

In the same context, based on a sample of 23 OECD countries and over a period from 1990 to 2010, Hathek. Z and Mrad. F [32] found a significant link between the institutional framework and economic growth. Good institutions are those that promote the relationship between open trade policies and the country's economic growth.

Thus, Zghidi et al [9] used the dynamic generalized momentum method for a sample composed of four African countries namely, Tunisia, Morocco, Egypt and Algeria over a 
period from 1980 to 2013 . They have showed that the increased volatility of FDI is justified by the good quality of public services and the balance between good governance strategies. Ezeoha and Ugwu [33] who clearly reveal the harmful effect of the consolidation of oppositions on the attractiveness of investment flows also verify this hypothesis. Thus, following the poor regulation of activities and the concern for freedom of opinion and the absence of anti-corruption reforms, FDI never reaches their volatility.

The arguments cited in the preceding part posed the following hypothesis:

$\mathrm{H}$ : Economic freedom has a positive and significant impact on FDI.

The conclusion of the literature review is as follows: The impact of economic freedom on foreign direct investment is significantly positive. In this context, we have successfully presented the methodology used to fully explore the influence of this proxy factor (economic freedom) on FDI inflows on a Tunisian scale.

\section{Data and Empirical Methodology}

\subsection{Data}

This study examines the macroeconomic impact of economic freedom on foreign direct investment (FDI) inflows into Tunisia over the period 1980-2017. The data for the index of economic freedom are published by the Heritage Foundation over the period 1980-2018, which represents the performance of the year 2017, but the data for macroeconomic variables (public expenditure and domestic investment and FDI are taken from The World Development Indicators Database (WDI, 2018) is the World Bank's main development database. The dependent variable is economic growth measured by real GDP per capita in 2005, the index of freedom measures the quality of institutions taking into account the size of the government, the sanctity of the currency, the protection of property rights, efficiency of the legal system and exchange with foreign countries. These variables are measured as five-year averages. Our static model combines all of the following variables that explain the regression of growth. In this empirical investigation, we try to contribute to the analysis of the impact of FDI, economic freedom on growth by demonstrating that economic freedom is considered a crucial factor in attracting FDI. We consider the equation in the following form:

$$
Y_{i, t}=\alpha_{0}+\alpha_{1} F D I_{i, t}+\alpha_{2} F E_{i, t}+\alpha_{3} X_{i, t}+\varepsilon_{\mathrm{i}, \mathrm{t}}
$$

Including GDP as an explanatory variable. We therefore pose the following equation.

$$
G D P_{i \mathrm{t}}=\alpha_{0}+\alpha_{1} F D I_{i \mathrm{t}}+\alpha_{2} F E_{i t}+\alpha_{3} X_{i t}+\varepsilon_{i t}
$$

Where: $\mathrm{i}$ represents the country, $\mathrm{t}$ represents the resulting period. $\mathrm{Y}$ is the annual growth rate (measured by GDP per capita). FDI is foreign direct investment (measured by the sum of equity re-investment of profits and other capital). FE the index of economic freedom (measured by the quality of institutions taking into account the size of government, the sanctity of money, the protection of property rights, The efficiency of the legal system and of trade with foreign countries. These variables are measured as five-year averages) $\mathrm{X}$ is the matrix of conditional variables that have an effect on growth; it includes domestic investment (measured by gross fixed capital formation) and government expenditure (measured by percentage of government expenditure). In addition, $\varepsilon$ is the error term.

We will introduce an interaction term to empirically analyze the interactive link between FDI and economic freedom; we obtained equation (3). The equation to estimate is:

$$
\begin{gathered}
G D P_{i t}=\alpha_{0}+\alpha_{1} F D I_{i t}+\alpha_{2} F E_{i, t}+\alpha_{3}\left(F D I_{i t} F E_{i t}\right)+ \\
\alpha_{4} G E_{i t}+\alpha_{5} I N V D_{i t}+\varepsilon_{i t}
\end{gathered}
$$

If the interaction term (FDI * FE) bears a positive sign, it implies the existence of a systemic link between FDI and growth that depends on a high degree of economic freedom.

\subsection{Empirical Methodology}

In this article, we used the generalized moment method; Arellano and Bond [34] and Arellano and Bover [35], and Blundell and Bond [36] introduce it. They constructed unbiased, convergent and asymptotically distributed estimators. Generally, this estimation method aims to correct the covariance variance matrix in order to take into account the autocorrelation problems and to eliminate any bias related to the unobserved individual heterogeneity; therefore, it offers a better efficiency of the estimation results.

$$
\begin{array}{r}
G D P_{i t}-G D P_{i, t-1}=\alpha\left(G D P_{i \mathrm{t}-1}-G D P_{i t-2}\right)+\alpha_{1}\left(F D I_{i t}-\right. \\
\left.F D I_{i \mathrm{t}-1}\right)+\alpha_{2}\left(F E_{i \mathrm{t}}-F E_{i \mathrm{t}-1}\right)+\alpha_{3}\left(X_{i, t}-X_{\mathrm{it}-1}+\left(\varepsilon_{i \mathrm{t}}-\varepsilon_{i t-1}\right.\right.
\end{array}
$$

Arellano and Bond [34] have proposed a more efficient estimator based on the use of additional instruments to find a solution to the problem of simultaneity of the explanatory variables as well as the correlation between $\left(y_{i, t-1}-y_{i, t-2}\right)$ and $\left(\varepsilon_{i, t}-\varepsilon_{i, t-1}\right)$ GMM method estimates use a strategy known as the first difference GMM estimator. The conditions of the generalized moments are presented as follows:

$$
\begin{gathered}
\mathrm{E}\left[\left(G D P_{i, t-s} \cdot\left(\varepsilon_{i, t}-\varepsilon_{i, t-1}\right)\right]=0 \text { pour } s \geq 2 ; \mathrm{t}=3 \ldots \mathrm{T}\right. \\
\mathrm{E}\left[\left(F D I_{i, t-s} \cdot\left(\varepsilon_{i, t}-\varepsilon_{i, t-1}\right)\right]=0 \text { pour } \mathrm{s} \geq 2 ; \mathrm{t}=3 \ldots \mathrm{T}\right. \\
\mathrm{E}\left[\left(F E_{i, t-s} \cdot\left(\varepsilon_{i, t}-\varepsilon_{i, t-1}\right)\right]=0 \text { pour } \mathrm{s} \geq 2 ; \mathrm{t}=3 \ldots \mathrm{T}\right. \\
\mathrm{E}\left[\left(X_{i, t-s} \cdot\left(\varepsilon_{i, t}-\varepsilon_{i, t-1}\right)\right]=0 \text { pour } \mathrm{s} \geq 2 ; \mathrm{t}=3 \ldots \mathrm{T}\right.
\end{gathered}
$$

However, several authors supported the idea of Arellano and Bond [34], which shows that the persistence of explanatory variables provides a weak instrument that can lead to a biased estimate of the parameters in a small sample and to a large asymptotic variance. Arellano and Bover [35] inspired another estimation strategy, which combines equation (4) and equation (1). The combination gives a new system estimator. Blundell and Bond [36] used Monte Carlo simulations to verify that this estimator increases the 
efficiency of the instruments used to reduce the bias and impressions associated with the difference estimator. The specific elements of the system-wide GMM estimator address the problems of endogeneity and omitted variable bias. However, endogeneity of variables and double causality are generally the two main problems in the GMM method. According to Arellano and Bover [35], the conditions of the additional moments of the second part of the system or of the level regression are written as follows:

$$
\begin{aligned}
& \mathrm{E}\left[\left(G D P_{i, t-s}-G D P_{i, t-s-1}\right) \cdot\left(\mu_{i}-\varepsilon_{i, t}\right)\right]=0 \text { for } \mathrm{s}=1 \\
& \mathrm{E}\left[\left(F D I_{i, t-s}-F D I_{i, t-s-1}\right) \cdot\left(\mu_{i}-\varepsilon_{i, t}\right)\right]=0 \text { for } \mathrm{s}=1 \\
& \mathrm{E}\left[\left(F E_{i, t-s} F E_{i, t-s-1}\right) \cdot\left(\mu_{i}-\varepsilon_{i, t}\right)\right]=0 \text { for } \mathrm{s}=1 \\
& \quad \mathrm{E}\left[\left(X_{i, t-s} \cdot X_{i, t-s-1}\right) \cdot\left(\mu_{i}-\varepsilon_{i, t}\right)\right]=0 \text { for } \mathrm{s}=1
\end{aligned}
$$

The consistency of the GMM estimator in system requires the conformance of the null hypothesis, which shows that the error term must not be correlated with the set of exogenous variables. In addition, that the model is correctly specified and the instruments are valid. The estimation results are presented in Table 1 .

Table 1. Estimation Results.

\begin{tabular}{lll}
\hline Variables & $\mathbf{( 1 )}$ & $\mathbf{( 3 )}$ \\
\hline 1. FDI & $(0.0440) 0.0749^{*}$ & $(0.06015) 0.00487$ \\
2. DInv & $(0.07091) 0.0825^{*}$ & $(0.075759) 0.07215$ \\
3. GE & $(-0.10072) 0.100^{*}$ & $(-0.101433) 0.1083$ \\
4. EF & $(0.17719)\left(0.0041^{* *}\right.$ & $(0.17926) 0.0093$ \\
5. FDI*FE & - & $(0.007633) 0.0908$ \\
6. R & 0.994383 & 0.994382 \\
\hline
\end{tabular}

Notes: Dependent variable is real GDP per Capita; the coefficient is indicated in parentheses. ${ }^{* *}$ Significant at $1 \%, * *$ significant at $5 \%, *$ significant at $10 \%$.

\section{Results}

The results of the estimate are presented in the previous table:

Column (1): impact of FDI and economic freedom on growth.

Column (3): estimate of the impact of the interaction between FDI and EF. The results of the estimation of the different equations are therefore more or less expected given the theoretical and empirical considerations already mentioned. Indeed, the essential conclusions of this empirical analysis reveal that the impact of FDI, in general, is a positive impact on economic growth in Tunisia, since the estimated coefficient of the variable (FDI) is equal to 0.040 positive and statistically significant at $10 \%$. The results confirm the importance of the positive role played by this attractive factor for the accumulation of economic growth in several countries. The coefficient of economic freedom has a positive sign $(0.177)$, so it has a positive and statistically significant effect at $5 \%$. Which shows that the economic growth of Tunisia and any other country in the world is increasing $s$ 'there is a high level of economic freedom index which enjoys several advantages thanks to the volatility generated by FDI flows, as well as a very high absorption capacity.
It should be noted that the coefficients of the control variables of our model are strictly positive and statistically significant at $10 \%$. In fact, the over identification of variables is overcome by the null hypothesis of correlations which can be rejected at the $5 \%$ level.

Subsequently, the column (3) presents the regression consequences that are justified by the use of an interaction term to capture the relationship between FDI and economic freedom. It has been found that the term of interaction is positive and statistically significant at $10 \%$, this shows that a strong presence of economic freedom strengthens FDI inflow and achieves economic growth otherwise the effect of FDI is correlated with the positive effect of economic freedom. Sargan's hypothesis or over-identification tests reveal that the instruments in our model are validated and correctly specified.

State participation is an important question in the promotion of economic freedom. This indicator takes into account both the level of government expenditure/GDP and the share of state enterprise revenue and monopoly in overall government revenue.

Generally, if public spending increases, the state decision replaces the appropriate choices for individuals, and economic freedom is thus reduced. The greater the importance of the State and its public enterprises, the more taxes must be paid for their financing and the less the private sector has the resources.

The positive effect of FDI inflows and the negative effect of public spending on economic growth increase monotonically with the importance of economic freedom in Tunisia. Note that the explanatory power $\left(\mathrm{R}^{2}\right)$ is equal to 0.99 . Thus, we can conclude that this statistic is close to 1 , which implies that there is a strong linear relationship between the different variables, and that the variables used as explanations explain $99 \%$ the variability of the economic growth of our country.

\section{Conclusions}

By way of conclusion, this analysis allowed us to show the existence of a complementary relationship between economic freedom, FDI and economic growth. As well as to detect some essential channels through which the beneficial effects of FDI could pass, it is about the economic freedom on the performance.

The empirical results of this research verify the positive relationship between the three variables of our estimation. Ipso facto, the regulatory intervention of efficient institutions creates a healthy and more attractive institutional environment for the entry of new investors into the market.

Our study is based on the GMM estimator. We use Tunisian data over a period from 1980 to 2017 . We observe three conclusions: The IDE simulates economic growth in a positive way. Economic freedom is an important factor of economic growth for Tunisia. The effect of FDI on economic growth requires a high level of $\mathrm{EF}$ in host countries.

The improvement of FDI volatility in Tunisia must be achieved through a chronological structuring of the reforms and through a well-defined action plan. We can then deduce some policies and reforms to invite Tunisia to benefit more from the positive inflows of FDI. It is necessary to liberalize 
commercial transactions more, to create jobs, to stop the unemployment of graduates, to attract activities of high knowledge, etc.

\section{Acknowledgements}

We would like to thank the anonymous reviewers for their valuable suggestions.

\section{References}

[1] FMI, F. M. I. (1993). Balance of Payments and International Investment Position Manual-Gelb, A., V. Ramachandran and G. Turner (2007), 'Stimulating Growth and Investment in Africa: from Macro to Micro Reforms', African Development Review, Vol. 9, No. 1, pp. 26-51.

[2] Dunning, J. (1993), Multinational Enterprises and the Global Economy, Addison-Wesley, Wokingham.

[3] Xu, B. (2000), 'Multinational Enterprises, Technology Diffusion, and Host Country Productivity Growth', Journal of Development Economics, Vol. 62, pp. 477-93.

[4] Kohpaiboon, Archanun. (2004). "Foreign Trade Regime and FDI-Growth Nexus: A Case Study of Thailand", Working paper, Australian National University.

[5] Worth, Thomas. (2004). "Regional Trade Agreements and Foreign Direct Investment", Working paper, Regional Trade Agreements and U.S. Agriculture/AER-771-77, Economic Research Service/USDA.

[6] Nath, Hiranya K. (2004). "Trade, Foreign Direct Investment and Growth: Evidence from Transition Economies", paperprepared for the $51^{\text {st }}$ Annual North American Meeting of the Regional Science Association International.

[7] Alfaro, L., A. Chanda, S. Kalemli-Ozcan and S. Sayek (2010), 'DoesForeign Direct Investment Promote Growth? Exploring the Role of Financial Markets on Linkages', Journal of Development Economics, Vol. 61, pp. 242-56.

[8] Blomstrom, M., R. Lipsey and M. Zejan (1994), 'What Explain Developing Country Growth?' in W. Baumol, N. Nelson and E. Wolff (eds.), Convergence and Productivity: Cross-National Studies and Historical Evidence, PN Oxford University Press, PLOxford.

[9] Zghidi, N., Mohamed Sghaier, I., \& Abida, Z. (2016). Does economic freedom enhance the impact of foreign direct investment on economic growth in North African Countries ? A panel data Analysis. African Development Review, 28 (1), 64-74.

[10] Krugman, P. (2000), 'Fire-sale FDI', in S. Edwards (ed.), Capital Flows and the Emerging Economies, The University of Chicago Press, Chicago.

[11] Stiglitz, J. E. (2000), 'Capital Market Liberalization, Economic Growth, and Instability', World Development, Vol. 28, No. 6, pp. $1075-86$

[12] Alaya. M, et al (2009) «À quelles conditions les IDE stimulent-ils la croissance?» Mondes en développement 2009/4 (n¹48), p. 119-138.

[13] Aitken, B., G. Hanson and A. Harrison (1997), 'Spillovers, Foreign Investment, and Export Behavior', Journal of
International Economics, Vol. 43, pp. 103-32.

[14] Agosin, M., \& Mayer, R. (2000). Foreign direct investment: Does it crowd in domestic investment. In United Nations Conference on Trade and Development Geneva, Switzerland, Working Paper (Vol. 146).

[15] ERSOY, A. Y., \& AALIOUA, M. (2018). The effect of foreign direct Investments on the economic growth of the mediterranean countries: case of turkey and morocco. Electronic Turkish Studies, 13 (14).

[16] Mohamed, S. E., \& Sidiropoulos, M. G. (2010). Another look at the determinants of foreign direct investment in MENA countries: an empirical investigation. Journal of economic development, 35 (2), 75 .

[17] Gwartney, J., \& Lawson, R. (2003). The concept and measurement of economic freedom.

[18] Gwartney, J., Lawson, R., \& Norton, S. (2008). Economic freedom of the world: 2008 annual report. The Fraser Institute.

[19] Hall, J. C., \& Lawson, R. A. (2014). Economic freedom of the world: An accounting of the literature. Contemporary Economic Policy, 32 (1), 1-19.

[20] Azman-Saini, W. N. W., Baharumshah, A. Z., \& Law, S. H. (2010). Foreign direct investment, economic freedom and economic growth: International evidence. Economic Modelling, 27 (5), 1079-1089.

[21] Quazi, R. (2007), 'Economic Freedom and Foreign Direct Investment in East Asia', Journal of the Asia Pacific Economy, Vol. 12, No. 3, pp. 329-44.

[22] Fabro, G., and J. Aixal a (2012), 'Direct and Indirect Effects of Economic and Political Freedom on Economic Growth', Journal of Economic Issues, Vol. 46, pp. 1059-80.

[23] Heckelman, J. C. (2000). Economic freedom and economic growth: A short-run causal investigation. Journal of Applied Economics, 3 (1), 71-91.

[24] Sambharya, R. B., \& Rasheed, A. A. (2015). Does economic freedom in host countries lead to increased foreign direct investment?. Competitiveness Review.

[25] Pearson, D., Nyonna, D., \& Kim, K. J. (2012). The relationship between economic freedom, state growth and foreign direct investment in US states. International Journal of Economics and Finance, 4 (10), 140-146.

[26] Medina-Moral, E., \& Montes-Gan, V. J. (2018). Economic freedom, good governance and the dynamics of development. Journal of Applied Economics, 21 (1), 44-66.

[27] Sovbetov, Y. (2017). Interaction of Economic Freedom and Foreign Direct Investment Globally: Special Cases from Neglected Regions. Journal of Economics and Financial Analysis, 1 (1), 59-80.

[28] Sooreea-Bheemul, B., Rasool, U. S., \& Sooreea, R. (2020). Does Economic Freedom Matter to Foreign Direct Investment in Sub-Saharan Africa?. International Journal of Economics and Financial Issues, 10 (3), 195-207.

[29] Suleymanov, E., \& Alirzayev, E. (2019). Role of Economic Freedom in Attracting Investments in the Context of Azerbaijan. International Journal of Economics and Financial Issues, 9 (1), 87-95. 
[30] Singh, D., \& Gal, Z. (2020). Economic Freedom and its Impact on Foreign Direct Investment: Global Overview. Review of Economic Perspectives, 20 (1), 73-90.

[31] Arslan, A., Tarba, S. Y., \& Larimo, J. (2015). FDI entry strategies and the impacts of economic freedom distance: Evidence from Nordic FDIs in transitional periphery of CIS and SEE. International Business Review, 24 (6), 997-1008.

[32] Hadhek, Z., \&Mrad, F. (2015). Trade Openness, Institutions and Economic Growth. European Journal of Economics, Finance and Administrative Sciences, 75, 96-104.

[33] Ezeoha, A. E., \& Ugwu, J. O. (2015). Interactive impact of armed conflicts on foreign direct investments in Africa. African Development Review, 27 (4), 456-468.
[34] Arellano, M. and S. Bond (1991), 'Some Tests of Specification for Panel Data: Monte Carlo Evidence with an Application for Employment Equations', Review of Economic Studies, Vol. 58, pp. 277-9.

[35] Arellano, M. and O. Bover (1995), 'Another Look at the Instrumental-Variable Estimation of Error-components Models', Journal of Econometrics, Vol. 68, pp. 29-52.

[36] Blundell, R; \& Bond, S. (1998). Initial conditions and moment restrictions in dynamic panel data models. Journal of Econometrics, 87 (1), 115-143. 